\title{
Albino Skin Cancer will End if a Communitys Cancer Surveillance Program is Successful
}

\section{Onuigbo WIB*}

Medical Foundation and Clinic, 8 Nsukka Lane, PO Box 1792, Enugu 400001, Nigeria

"Corresponding author: Wilson IB Onuigbo, Medical Foundation and Clinic, 8 Nsukka Lane, PO Box 1792, Enugu 400001, Nigeria, Tel: +2348037208680; E-mail: wilson.onuigbo@gmail.com

Rec date: Dec 10, 2015; Acc date: Jan 09, 2016; Pub date: Jan 11, 2016

Copyright: ( 2016 Onuigbo WIB. This is an open-access article distributed under the terms of the Creative Commons Attribution License, which permits unrestricted use, distribution, and reproduction in any medium, provided the original author and source are credited.

\begin{abstract}
The new emphasis on cancer surveillance research (CSR) encompasses many approaches. Therefore, this paper examines the huge problem raised by the burden of cancer on Nigerian albinos. First, its grievousness is illustrated. Next, it is advanced that shielding albinos from sunlight right from childhood will repay dividends, especially if mothers are attentive and Governments are admissive of a most moving message, namely, that the preventive policy option is that indoor employment should be reserved for these disadvantaged members of the population.
\end{abstract}

Keywords: Albino skin cancer; Dermatologist; Cancerous ulcers

\section{Introduction}

According to Anderson [1] cancer surveillance research (CSR) "can aid health care planners and policy makers manage and direct limited resources". Therefore, this paper directs attention to albinos, whom Okoro [2] a Nigerian dermatologist, espoused on back in 1975 as regards the development of sunlight induced skin cancer. Of late, the affected patients have generally been prone to present rather late [3-6]. Consequently, an index has been sought to highlight the heaviness of the problem not only as regards its exact measurement, but also with regard to the simpleness of its surveillance, especially in terms of government policy of statutory indoor employment.

\section{Materials and Methods}

Since 1970, the author has manned the Regional Pathology Laboratory of the erstwhile Eastern Region of Nigeria. Having insisted on adequate provision of the clinical details accompanying the Laboratory Request Forms, it was relatively easy to document the details concerning albino patients of the Ibo or Igbo ethnic group [7]. In particular; age, sex, and size in $\mathrm{cm}$ of the surgically excised cancerous ulcers were systematically documented.

\section{Results}

Table 1 portrays the age / sex patterns, while Table 2 highlights the maximum diameter in $\mathrm{cm}$ of the submitted specimens. Figure 1 is explanatory. Note albino skin wedge excision specimen in which a previous biopsy scar appears next to a new crateriform lesion. It will be seen that the present lesion is up to $5 \mathrm{~cm}$ across. In all probability, the earlier lesion was of the same duration and dimension.

\section{Discussion}

The stark reality in the field of the age-period-cohort (APC), as emphasized by Rosenberg and Anderson [8] is important in the present series just as elsewhere. Thus, males accounted for 182 cases and females 91, i.e., roughly 2:1 ratio. The 20-29 cohort abounded. These parameters are indications of the occupational exposure during youthful labouring ages.

\begin{tabular}{|l|l|l|l|}
\hline Age Group & M & F & Total \\
\hline $10-19$ & 20 & 5 & 25 \\
\hline $20-29$ & 50 & 39 & 89 \\
\hline $30-39$ & 48 & 25 & 73 \\
\hline $40-49$ & 33 & 14 & 47 \\
\hline $50-59$ & 11 & 4 & 15 \\
\hline $60-69$ & 7 & 3 & 10 \\
\hline $70-79$ & 3 & 1 & 4 \\
\hline Total & 172 & 91 & 263 \\
\hline
\end{tabular}

Table 1: Distribution by age and sex of the afflicted albinos.

\begin{tabular}{|l|l|l|}
\hline \multirow{2}{*}{ Lesions $(\mathbf{c m})$} & Patients & $\mathbf{( \% )}$ \\
\cline { 2 - 3 } & $\mathbf{( N o . )}$ & 3.4 \\
\hline 1 & 10 & 10.2 \\
\hline 2 & 27 & 15.6 \\
\hline 3 & 41 & 20.9 \\
\hline 4 & 55 & 49.9 \\
\hline $5+$ & 130 & 100 \\
\hline Total & 263 & \\
\hline
\end{tabular}

Table 2: Measurements in cm of 263 excised albino skin cancers. 
Citation: Onuigbo WIB (2016) Albino Skin Cancer will End if a Communitys Cancer Surveillance Program is Successful. J Health Edu Res Dev

Page 2 of 2

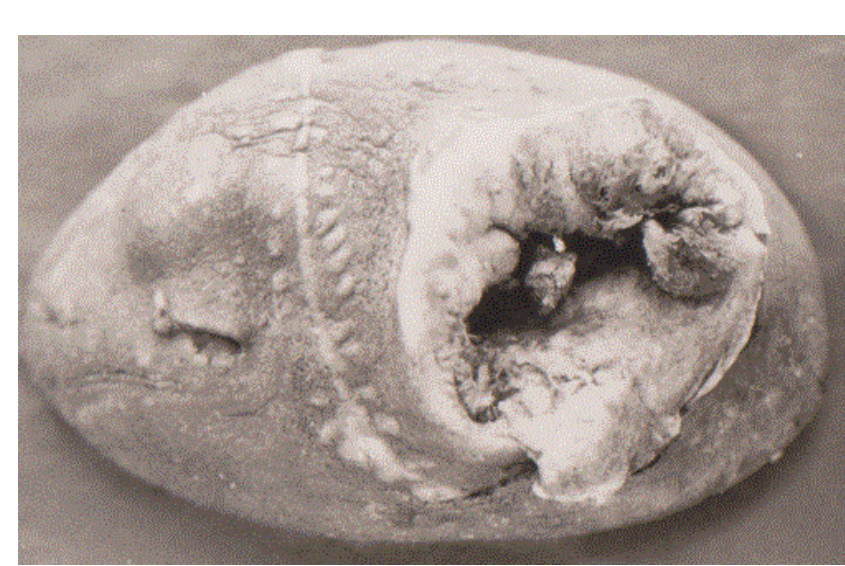

Figure 1: Albino skin ellipse showing needle punctures from previous tumor biopsy and adjacent crateriform cancer.

Since exposure to sunlight is the undoubted cause of albino skin cancers, is there in the Nigerian populace a decidedly different group worthy of exemplification? In my own experience, there can decidedly be a zero tolerance for sunlight exposure. Indeed, it has been exhibited by two albino female medical students. Thus, over the years, they have become consultant physicians without even any facial blemish.

I am persuaded that both of them constitute, with singularity, two shining examples of what is possible in practice in the entire community. It is hypothesized that, this can be achieved if mothers take particular care of albinos. Moreover, apart from the traditional public health education [9] there is the fundamental question of employment. Incidentally, Northern Nigerian authors [10] suggested that albinos should themselves seek indoor rather than outdoor occupation. Not really! Rather, there should be a solid governmentplanned public policy of indoor employment for these disadvantaged citizens.

\section{Conclusion}

It was recently stated concerning "The War on Cancer" by Sporn [11] that "Too many adults still die from common epithelial cancers." The thrust of the present paper is that not a single albino should even come to grief let alone die of squamous cell carcinoma of the skin. This will certainly come to pass if the above documented surveillance is firmly rigid from childhood and Government's policy option is equally firmly guaranteed regarding indoor employment for the disadvantaged albino.

\section{References}

1. Anderson WF (2009) Cancer surveillance research. J Cancer Epidemiol Biomarkers Prev 18: 166.

2. Okoro AN (1975) Albinism in Nigeria. A clinical and social study. Br J Dermatol 92: 485-492.

3. Asuquo ME, Ngim O, Ebughe G, Bassey EE (2009) Skin cancers amongst four Nigerian albinos. Int J Dermatol 48: 636-638.

4. Kiprono SK, Chaula BM, Beltraminelli H (2014) Histological review of skin cancers in African Albinos: a 10-year retrospective review. BMC Cancer 14: 157.

5. Mabula JB, Chalya PL, Mchembe MD (2012) Skin cancers among albinos at a University teaching hospital in Northwestern Tanzania: a retrospective review of 64 cases. BMC Dermatology 12: 5 .

6. Opara KO, Jiburum BC (2010) Skin cancers in albinos in a teaching Hospital in eastern Nigeria-presentation and challenges of care. World J Surg Oncol 8: 73.

7. Basden GT (1966) Niger Ibos. London Cass.

8. Rosenberg PS, Anderson WF (2011) Age-period-cohort models in cancer surveillance research: ready for prime time. Cancer Epidemiol Biomarkers Prev 20: 1263-1268.

9. Kromberg JG, Castle D, Zwane EM, Jenkins T (1989) Albinism and skin cancer in Southern Africa. Clin Genet 36: 43-52.

10. Yakubu A, Mabogunje OA (1993) Skin cancer in African albinos. Acta Oncol 32: 621-622.

11. Sporn MB (1996) The war on cancer. Lancet 347: 1377-1381. 